\title{
EFFECTS OF UTERINE DISTENSION ON THE OESTROUS CYCLE OF THE COW
}

\author{
M. YAMAUCHI, T. NAKAHARA, Y. KANEDA AND S. INUI \\ Chugoku Branch, National Institute of Animal Health, Wadayama, Hyogo, Japan
}

(Received 1st March 1966, revised 11th Fuly 1966)

Summary. The effects on the oestrous cycle of the cow of uterine distension caused by injecting a viscous gel-like substance into the uterus were investigated. Intra-uterine injection in the early luteal phase shortened the cycle length in thirteen of fourteen cases, giving a mean of 12.5 days $(P<0.01)$. Treatments during the late luteal phase lengthened the cycle in five animals, giving a mean of 25.8 days $(P<0.01)$. Cycles were of normal length in ten of twelve cases treated at post-oestrus, functional luteal phase or pro-oestrus. In twenty-three of twenty-five cycles in which the treatments were performed between early luteal phase and late luteal phase, the mean length from the treatment to ovulation was $9 \cdot 3 \pm 1 \cdot 6$ days, suggesting that intra-uterine treatment is effective in synchronizing the oestrous cycle and ovulation in cows except during pro-oestrus, oestrus and post-oestrus. Gel treatment produced a temporary endometritis associated with cloudy mucus and numerous leucocytes and epithelial cells in the vagina. The retention of gel in the uterus was longer in animals treated at late luteal phase than in those treated at early luteal phase. Of six animals which received the intra-uterine treatment during early luteal phase three became pregnant after artificial insemination.

\section{INTRODUCTION}

It has been reported that a mechanism involving the uterus modifies the lifespan of the corpus luteum. In the guinea-pig (Moore, 1961; Donovan, 1961; Donovan \& Traczyk, 1960), ewe (Moore \& Nalbandov, 1953; Nalbandov, Moore \& Norton, 1955; Inskeep, Oloufa, Howland, Pope \& Casida, 1962) and cow (Yamauchi \& Nakahara, 1958; Hansel \& Wagner, 1960) the length of the oestrous cycle can be modified by uterine distension. In the cow, Yamauchi \& Nakahara (1958) reported the effects of uterine distension on the oestrous cycle. Rubber tubes ( $6 \mathrm{~mm}$ in diameter and 3 to $9 \mathrm{~cm}$ long) were inserted into the uterine horn 1 to 3 days (early luteal phase) or 7 to 8 days (functional luteal phase) after ovulation. The mean oestrous cycle length was reduced to 10.7 days and 16.6 days, respectively. Hansel \& Wagner (1960) observed a similar effect on the cycle length of cows when a rubber catheter was inserted into the uterus during the first 7 days of the cycle. These results suggest that the uterus plays an important role in regulating oestrous cycle length and luteal function. This paper describes the effects on the length of the oestrous cycle of the cow of the injection of a viscous substance into the uterus. 


\section{MATERIALS AND METHODS}

Two experiments examining the effects of intra-uterine injection of a viscous substance on the oestrous cycle of the cow were carried out. Three other experiments were conducted to determine: (1) the effective period of uterine distension for modifying cycle length, (2) the irritating effect of the treatment on the bovine endometrium, and (3) the fertility of the animal following treatment.

In Experiments 1 and 2, nine cows (seven Japanese beef cows and two Jersey cows) were used. Normal oestrous cycles (19 to 24 days) were observed in all animals for 2 or 3 months before they were used in the experiment. Uterine distensions were performed on one to eight oestrous cycles in each animal for a total of thirty-four cycles. An animal was not re-treated until she had shown one to three cycles of a normal length after a treatment cycle.

Uterine distension was produced by injecting a viscous gel-like substance 'Gelceptor F' through the cervix into the uterus. The formulation was prepared originally for treating endometritis in cows and contains $500 \mathrm{mg}$ of Fradiomycin sulphate, $280 \mathrm{mg}$ of Bithionol and 10,000 i.u. of vitamin A palmitate $/ 100 \mathrm{~g}$ of gel. Gelceptor $\mathbf{F}$ is supplied in $75 \mathrm{~g}$ plastic tubes and was transferred directly from the container to the uterus by means of a device designed by the authors. A metal catheter was arranged so that it could be screwed directly onto the nozzle of the plastic tube. The mixture was then expelled through the catheter by rolling a cylinder attached to the base of the plastic tube towards the nozzle. At each injection 42 to $137 \mathrm{~g}$ of the material was administered. The day on which ovulation occurred was considered as Day 0 of the cycle.

In Experiment 1, Gelceptor F was injected into five animals, once on Day 2 and once on Day 5 or 6 (early luteal phase) while in four other animals, two or five injections were given from Day 12 to Day 21 (functional luteal phase to late luteal phase).

In Experiment 2, single or double intra-uterine treatments were performed at various stages of the oestrous cycle: in four cycles treatment was performed on Day 1 (post-oestrus), in five cycles on Day 2 (early luteal phase), in four cycles on Day 6 (early luteal phase), in four cycles on Day 12 (functional luteal phase), in three cycles on Days 14 and 16 (late luteal phase), in three cycles on Day 17 or 18 (late luteal phase) and in two cycles on Day 17 or 18 (pro-oestrus).

After the intra-uterine treatment in Experiments 1 and 2, the ovaries and the uterus were examined by rectal palpation at intervals of 1 to 3 days. Oestrous behaviour was checked daily with a vasectomized bull. The length of a treatment cycle was compared with those of the previous and subsequent untreated cycles.

In Experiment 3, the effective period of uterine distension for modifying the oestrous cycle length was investigated. On Days 2 or 6,60 to $140 \mathrm{~g}$ of Gelceptor $F$ were injected into the uterus of each of six beef cows. Two days after the treatment, uterine contents were removed by uterine irrigation with 800 to $1500 \mathrm{ml}$ of sterilized saline and the effects on length of oestrous cycles noted.

In Experiment 4, the irritating effect of the gel on the endometrium was studied. The endometrium was examined histologically in eight beef cows 
slaughtered 1 to 9 days after the intra-uterine treatment. In an additional five cases, the endometrium at the first post-treatment oestrus was also examined histologically by endometrial biopsy.

In Experiment 5, the fertility of cows after the intra-uterine treatment was examined. Five cows and one heifer were used and the cows had calved 100 days or more before the beginning of this experiment. Normal oestrous cycles had been observed in all animals and they had not become pregnant following two to six services. They received a single intra-uterine injection of gel during the luteal phase: three animals were treated on Day 4, two animals on Day 5, and one animal on Day 12. They were artificially inseminated at the first post-treatment oestrous period. Pregnancies were checked by rectal palpation 50 to 60 days after insemination.

\section{RESULTS}

The results of Experiment 1 are shown in Table 1. In five cows which received double treatments at early luteal phase, the mean length of the treatment cycles was reduced to 11.9 days, while those of the previous and following cycles

TABLE 1

MODIFICATION OF OESTROUS CYGLE OF THE COW BY SUCCESSIVE INTRA-UTERINE INJECTIONS OF GELCEPTOR F

\begin{tabular}{|c|c|c|c|c|c|c|c|c|c|}
\hline \multirow{2}{*}{$\begin{array}{l}\text { Time of } \\
\text { treatment }\end{array}$} & \multirow{2}{*}{$\begin{array}{l}\text { No. of } \\
\text { cows }\end{array}$} & \multirow{2}{*}{$\begin{array}{c}\text { No. of } \\
\text { injections }\end{array}$} & \multirow{2}{*}{$\begin{array}{c}\text { Day of } \\
\text { injection }\end{array}$} & \multicolumn{2}{|c|}{$\begin{array}{c}\text { Previous cycle } \\
\text { untreated (days) }\end{array}$} & \multicolumn{2}{|c|}{$\begin{array}{c}\text { Treatment } \\
\text { cycle (days) }\end{array}$} & \multicolumn{2}{|c|}{$\begin{array}{c}\text { Following cycle } \\
\text { untreated }(\text { days })\end{array}$} \\
\hline & & & & Mean & Range & Mean & Range & Mean & Range \\
\hline $\begin{array}{l}\text { Early luteal } \\
\text { phase }\end{array}$ & 5 & 2 & $\begin{array}{l}2 \text { and } \\
5 \text { or } 6\end{array}$ & $20 \cdot 4$ & 19 to 22 & 11.9 & 9 to 14 & $21 \cdot 6$ & 19 to 23 \\
\hline $\begin{array}{l}\text { Functional- } \\
\text { late luteal } \\
\text { phase }\end{array}$ & 4 & $\begin{array}{c}2 \\
\text { or } \\
5\end{array}$ & $\left|\begin{array}{c}12 \text { and } 16 \\
\text { or } \\
12 \text { to } 21\end{array}\right|$ & $22 \cdot 8$ & 21 to 24 & $24 \cdot 3$ & 20 to 28 & $22 \cdot 3$ & 21 to 24 \\
\hline
\end{tabular}

without treatment were 20.4 and 21.6 days, respectively. In the treatment cycles the corpus luteum degenerated earlier than in the normal cycle and rapid follicular development followed. Ovulation occurred between Days 9 and 14 . In four animals which received two or five treatments during the functionallate luteal-phase, two of the treatment cycles were lengthened and two were not; the mean length of the cycles was $24 \cdot 3$ days. Since cycle length was modified by the intra-uterine treatment in this preliminary experiment, the relation between the time of the treatment and the cycle length was next investigated.

The results of Experiment 2 are shown in Table 2 and are summarized as follows:

(1) In four cows treated on Day 1 (post-oestrus), one of the cycles was reduced to 8 days and the remaining three cycles were of normal length; the mean cycle length was 18.5 days.

(2) In five cows treated on Day 2 (early luteal phase), the mean cycle length was reduced to 12.0 days. The shortening of the cycle was significant statistically $(P<0.05)$. 
(3) In four cows treated on Day 6 (early luteal phase), the mean cycle length was shortened to 15.5 days $(P<0 \cdot 01)$.

(4) In four cows treated on Day 12 (functional luteal phase), the mean length of cycles was 21.3 days. It was not different from those of the previous and following cycles in these animals.

(5) In three cows treated on Days 14 and 16 (late luteal phase), all of the cycles were lengthened, the mean cycle length being $24 \cdot 7$ days.

TABLE 2

MODIFICATION OF OESTROUS GYGLE OF THE COW BY SINGLE OR DOUBLE INTRA-UTERINE INJECTIONS OF GELCEPTOR AT VARIOUS STAGES OF GYGLE

\begin{tabular}{|c|c|c|c|c|c|c|c|}
\hline & \multicolumn{7}{|c|}{ Time of treatment } \\
\hline & \multirow{2}{*}{$\frac{\text { Post-oestrus }}{\text { Day } 1}$} & \multicolumn{2}{|c|}{ Early luteal phase } & \multirow{2}{*}{$\begin{array}{c}\begin{array}{c}\text { Functional } \\
\text { luteal } \\
\text { phase }\end{array} \\
\text { Day } 12\end{array}$} & \multicolumn{2}{|c|}{ Late luteal phase } & \multirow{2}{*}{$\begin{array}{c}\text { Pro-oestrus } \\
\text { Days } \\
17 \text { or } 18\end{array}$} \\
\hline & & Day 2 & Day 6 & & $\begin{array}{c}\text { Days } \\
14 \text { and } 16\end{array}$ & $\begin{array}{l}\text { Days } \\
17 \text { or } 18\end{array}$ & \\
\hline $\begin{array}{l}\text { Length of } \\
\text { cycles (days) }\end{array}$ & $\begin{array}{l}20-20 \\
22-8-23 \\
23-25-22 \\
20-21\end{array}$ & $\begin{array}{l}21-22-20 \\
22-9-23 \\
21-10-27 \\
24-10-21 \\
22-9-21\end{array}$ & $\begin{array}{l}23-14-27 \\
22-17-19 \\
26-17-25 \\
20-14-21\end{array}$ & $\begin{array}{l}20-20-20 \\
22-21-20 \\
22-22-22 \\
22-22-21\end{array}$ & $\begin{array}{l}20-24-22 \\
21-25-22 \\
21-25-23\end{array}$ & $\begin{array}{l}22-33-23 * \\
22-27-23 \\
23-28-22\end{array}$ & $\begin{array}{l}21-20-21 \\
19-19-21\end{array}$ \\
\hline $\begin{array}{l}\text { Mean cycle } \\
\text { length (days) }\end{array}$ & $\begin{array}{c}21 \cdot 2- \\
18 \cdot 5- \\
22 \cdot 5\end{array}$ & $\begin{array}{c}22 \cdot 0- \\
12 \cdot 0- \\
22 \cdot 4\end{array}$ & $\begin{array}{c}22 \cdot 8- \\
15 \cdot 5- \\
23 \cdot 0\end{array}$ & $\begin{array}{l}21 \cdot 5- \\
21 \cdot 3- \\
20 \cdot 8\end{array}$ & \multicolumn{2}{|c|}{$\begin{array}{c}21 \cdot 4-25 \cdot 8-22 \cdot 4 \\
(\text { except*) }\end{array}$} & $\begin{array}{l}20 \cdot 0- \\
19 \cdot 5- \\
21 \cdot 0\end{array}$ \\
\hline $\begin{array}{l}\text { Treatment } \\
\text { cycle compared } \\
\text { to previous and } \\
\text { following cycles } \\
\text { untreated }\end{array}$ & Various & $\begin{array}{c}\text { Shortened } \\
(P<0.05)\end{array}$ & $\begin{array}{c}\text { Shortened } \\
(P<0.01)\end{array}$ & $\begin{array}{c}\text { Not } \\
\text { different }\end{array}$ & \multicolumn{2}{|c|}{$\begin{array}{l}\text { Lengthened } \\
(P<0.01)\end{array}$} & $\begin{array}{c}\text { Not } \\
\text { different }\end{array}$ \\
\hline
\end{tabular}

Figures show the lengths of successive cycles, the italics indicating the cycle in which treatment was given.

* Treatment cycle was abnormally long.

(6) In three cows treated on Day 17 or 18 (luteal phase as judged by rectal palpation), the mean length of cycles was increased to 29.3 days. One cow had an abnormally long cycle in which a cystic follicle was present for about 10 days from the 2nd day after the treatment until ovulation occurred on Day 33. This case was considered exceptional.

In these two groups ( 5 and 6 ) treated at late luteal phase, except for one animal in which the treatment cycle was lengthened abnormally due to a cystic follicle, the mean cycle length was $25 \cdot 8$ days. The lengthening of the cycle was significant statistically $(P<0.01)$.

(7) In two cows treated on Days 17 or 18, the mean length of cycle was 19.5 days. This was not different from those of the previous and following cycles. At the time of treatment, these two animals were judged to be in pro-oestrus, as the corpus luteum had degenerated and follicles were developing in the ovaries and oestrous signs were noted. 
From the results of Experiments 1 and 2 (omitting two cases which received five successive treatments and one case in which the treatment cycle was abnormally long), it can be seen that shortening or lengthening of the oestrous cycle depended on the stage at which the treatment was performed. In ten of twelve cases treated at post-oestrus, functional luteal phase or pro-oestrus the cycles were of a normal length. No treatment was attempted at oestrus. In all fourteen cows treated in the early luteal phase the cycle length was shortened and in all five of the animals treated in the late luteal phase the cycle length was increased. In twenty-three of twenty-five cases in which the treatments were performed between early luteal phase and late luteal phase, ovulations occurred 7 to 12 days after the treatment, the mean length from the treatment to ovulation being $9 \cdot 3 \pm 1 \cdot 6$ days.

Retention of Gelceptor F in the uterus of the treated cows in Experiments 1 and 2 was verified by rectal palpation. In only three of sixteen cases treated during post-oestrus and in early luteal phase, were liquid contents in the uterus palpable for a few days after the treatment. After treatment during the functional luteal phase and the late luteal phase, uterine contents were palpable for 2 to 6 days in ten of sixteen cases. In five of the latter cases the uterus was swollen as in the case of pyometra or pregnancy and there was an accumulation of liquid. However, the swollen uterus involuted rapidly as the corpus luteum began to degenerate. By the time the animal returned to oestrus, the uterus had resumed normal size and motility in all cases. From these results it was concluded that the retention of Gelceptor $F$ in the uterus depended upon the stage at which the intra-uterine injection was performed, the retention period being longer in animals treated at functional-late luteal phase than in those treated at postoestrus-early luteal phase.

During twenty oestrous cycles included in Experiment 2, vaginal mucus samples were collected before and after treatment and examined macroscopically and microscopically. The microscopical examination was performed on the mucus smear stained with Giemsa. For 1 to 3 days after treatment, the vaginal mucus was cloudy and a large number of neutrophile leucocytes and epithelial cells were present in most cases. The vaginal mucus became clear again in the following oestrous period.

The effective period of uterine distension for modifying the cycle length was investigated in Experiment 3. The results obtained are as shown in Table 3. In all six cows in which Gelceptor $F$ was injected into the uterus on Day 2 or Day 6 and uterine contents removed by uterine irrigation with saline 2 days later, the oestrous cycles were shortened as in the cases in Experiments 1 and 2. These results suggested that uterine distension for a short period of less than 2 days, at least in early luteal phase, effectively modified the bovine oestrous cycle.

The ability of the gel to irritate the uterine endometrium was studied in Experiment 4. The endometria of eight cows slaughtered 1 to 9 days after the intra-uterine treatment were examined macroscopically and histologically. In six of the eight animals, 105 to $660 \mathrm{~g}$ of a reddish liquid was recovered from the uterine cavity. The volume of the uterine contents recovered was greater than the quantity of gel injected. The surface of the endometrium was rough and brownish in colour in seven of the animals. Marked oedema was also observed 
TABLE 3

LENGTH OF OESTROUS CYCLE WHEN GELCEPTOR F WAS REMOVED FROM THE UTERUS AFTER 2 DAYS

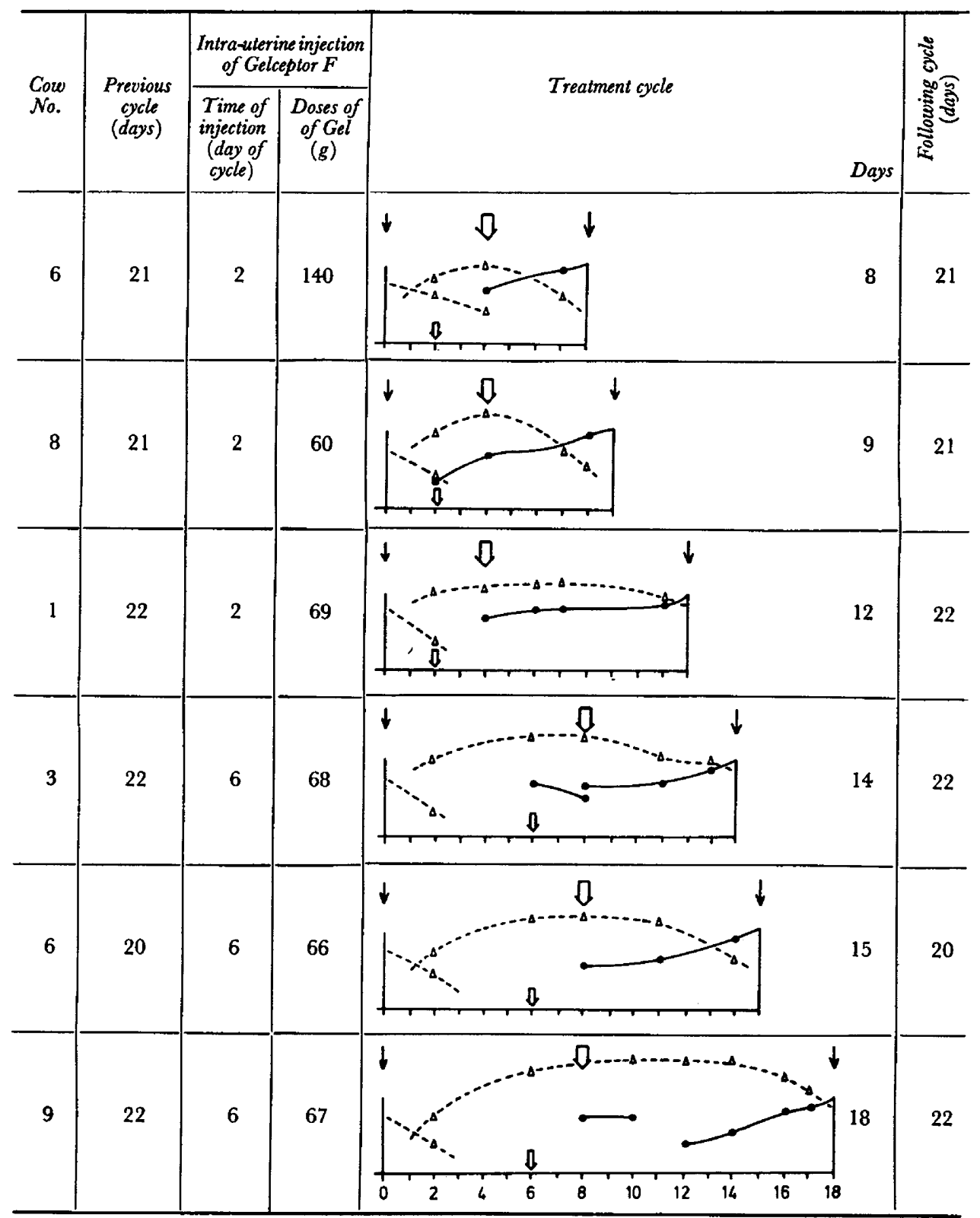

$\mathbb{0}$, Intra-uterine injection of $\mathrm{Gel} ; \mathbb{Q}$, uterine irrigation with saline; $\downarrow$, ovulation; $\bullet$, ovarian follicl $\mathrm{e}$; $\Delta$, corpus luteum. 
in the endometria of five animals. Histological examination of the endometrium showed no endometritis in four cases of endometrial biopsy performed just before the intra-uterine injection. Endometritis was found in five of the eight animals slaughtered after the treatment. However, the endometritis was limited to the surface area of the endometrium; the uterine glands appeared normal in all cases. Endometrial biopsies were also carried out at the posttreatment oestrous period in the five other cows. Endometritis was not found in any of the five animals. These endometrial findings seemed to correlate with observations of the vaginal mucus mentioned above. The results indicate that Gelceptor $\mathbf{F}$ is irritating to the bovine endometrium and endometritis was produced by injecting the preparation into the uterus at any stage of the cycle. By the time the animal returned to oestrus, the endometrium was normal.

In Experiment 5, the fertility of cows following the intra-uterine treatment was investigated. In five of the six animals which received single intra-uterine treatments on Days 4 to 12 , the length of the treatment cycle was reduced to 8 to 10 days. In the remaining animal treated on Day 12, the length of the treated cycle was 18 days. Oestrus occurred 4 to 6 days after the treatment in all six animals. They were inseminated at the first post-treatment oestrous period and three of them became pregnant. These results suggest that though the bovine oestrous cycle is modified by injecting Gelceptor $F$ into the uterus, follicular maturation and ovulation occur normally and the uterine conditions are suitable for conception in the following oestrous period.

\section{DISCUSSION}

In the present study it was found that the cycle length of the cow could be modified by uterine distension produced by injecting Gelceptor $\mathrm{F}$ into the uterus. The lengthening or shortening of the bovine oestrous cycle caused by the intra-uterine treatment seemed to be quite similar to that reported for the ewe by Moore \& Nalbandov (1953) who inserted plastic beads into the uterus.

Certain results suggest that a neurogenic stimulus from the distended uterine horn regulates the secretion of pituitary gonadotrophins. In the guinea-pig (Moore, 1961) and ewe (Moore \& Nalbandov, 1953), uterine distension produced by plastic beads has no effect upon the cycle length when the segment of the uterus containing the bead is denervated. Other evidence suggests that a luteolytic substance may be produced by the uterus. Hysterectomy during luteal phase of the cycle causes cessation of oestrus and persistence of active corpora lutea in the guinea-pig (Loeb, 1923; Rowlands, 1961), gilt (Anderson, Butcher \& Melampy, 1961), and heifer (Anderson, Neal \& Melampy, 1962). The length of the oestrous cycle following subtotal hysterectomy is correlated with the amount of uterine tissue remaining in these three species. In the present study it is not known if the bovine uterus distended by gel injection directly affects luteal function or if a neurogenic stimulus from the distended uterus modifies the secretion of pituitary gonadotrophins.

In recent years much interest has been centred on sychronization of the oestrous cycle in cattle, swine and ewes. For the purpose of the oestrous cycle synchronization in cattle, orally active progestins such as 6-methyl-17-acetoxy- 
progesterone (MAP) or 6-chloro- $\Delta^{5}$-dehydro-17-acetoxyprogesterone (CAP) have been used (Ray, Emerson \& Melampy, 1961; Hansel, Malven \& Black, 1961; Anderson, Ray \& Melampy, 1962; VanBlake, Brunner \& Hansel, 1963). These trials have been reasonably successful, but the relatively high cost of the progestins has been a limiting factor in the practical application. In the present investigation, it is important to note that ovulation occurs 7 to 12 days $(9 \cdot 3 \pm 1 \cdot 6$ days) after the intra-uterine injection of Gelceptor $F$ in a large proportion of cows in which the treatment was performed during the early, functional, or late luteal phase of the cycle. It is possible that the intra-uterine treatment is effective in synchronizing the oestrous cycle and ovulation in cattle except during the limited periods of pro-oestrus, oestrus and post-oestrus.

\section{REFERENCES}

Anderson, L. L., Butcher, R. L. \& Melampy, R. M. (196I) Subtotal hysterectomy and ovarian function in gilts. Endocrinology, 69, 571 .

Anderson, L. L., Neal, F. C. \& Melampy, R. M. (1962) Hysterectomy and ovarian function in beef heifers. Am. F. vet. Res. 23, 794.

Anderson, L. L., Ray, D. E. \& Melampy, R. M. (1962) Synchronization of estrus and conception in the beef heifer. 7. Anim. Sci. 21, 449.

Donovan, B. T. (1961) The role of the uterus in regulation of the oestrous cycle. F. Reprod. Fert. 2, 508.

Donovan, B. T. \& Traczyk, W. (1960) Uterine distention and the vaginal cycle in the guinea pig. 7. Physiol., Lond. 154, 50.

Hansel, W., Malven, P. V. \& Black, D. L. (1961) Estrous cycle regulation in the bovine. 7. Anim. Sci. 20, 621 .

HANSEL, W. \& WAGNER, W. C. (1960) Luteal inhibition in the bovine as a result of oxytocin injections, uterine dilatation, and uterine infusions of seminal and preputial fluids. F. Dairy Sci. 43, 796.

Inskeep, E. K., Oloufa, M. M., Howland, B. E., Pope, A. L. \& Casba, L. E. (1962) Effect of experimental uterine distention on estrous cycle lengths in ewes. $\mathcal{J}$. Anim. Sci. 21, 331.

LOEB, L. (1923) The effect of extirpation of the uterus on the life and function of the corpus luteum in the guinea pig. Proc. Soc. exp. Biol. Med. 20, 441.

MOORE, W. W. (1961) Effect of uterine distention on the estrous cycle of the guinea pig. Physiologist, Wash. 4, 76.

Moore, W. W. \& Nalbandov, A. V. (1953) Neurogenic effects of uterine distention on the estrous cycle of the ewe. Endocrinology, 53, 1.

Nalbandov, A. V., Moore, W. W. \& Norton, H. W. (1955) Further studies on the neurogenic control of the estrous cycle by uterine distention. Endocrinology, 56, 225.

Ray, D. E., Emmerson, M. A. \& Melampy, R. M. (1961) Effect of exogenous progesterone on reproductive activity in the beef heifer. J. Anim. Sci. 20,373.

Rowlands, I. W. (1961) Effect of hysterectomy at different stages on the life cycle of the corpus luteum in the guinea-pig. 7. Reprod. Fert. 2, 341.

VanBlake, H., Brunner, M. A. \& Hansel, W. (1963) Use of 6-chloro- $\Delta^{6}$-dehydro-17-acetoxyprogesterone (CAP) in estrous cycle synchronization of dairy cattle. 7. Dairy Sci. 46, 459.

YAMAUCHI, M. \& NAKAHARA, T. (1958) Effects of uterine distention on the estrous cycle of the bovine. Jap. F. Anim. Reprod. 3, 121. 